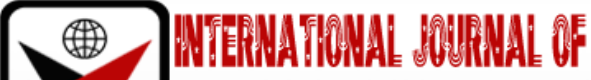

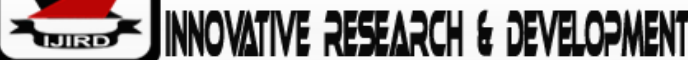

ISSN 2278-0211 (Online)

\section{Implementation of Hospitality Programme to Facilitate Skills Acquisition among Trainees in Arusha Region, Tanzania}

Sharifa Mbagga
Ph.D. Candidate, Department of Psychology, Measurements, Evaluation and Curriculum
Studies (PMECS), Mwenge Catholic University, Kilimanjaro, Tanzania
Dr. Joseph Malusu
Senior Lecturer, Department of Psychology, Measurements, Evaluation and Curriculum
Studies (PMECS), Mwenge Catholic University, Kilimanjaro, Tanzania
Dr. Eugene Lyamtane
Senior Lecturer, Department of Psychology, Measurements, Evaluation and Curriculum
Studies (PMECS), Mwenge Catholic University, Kilimanjaro, Tanzania

\begin{abstract}
:
Tourism and hospitality as a labour-intensive industry is forecasted to continue growing despite various turbulent in different parts of the world. As the sector continue to evolve, the need for skilled human resources increases. However, industry professionals are complaining about the quality of human resources. While some authors have addressed the issue in relation to graduates' skills possession and the nature of services they render, the researcher could not find a study that has addressed the issue in relation to how this programme is implemented to facilitate skills acquisition among college trainees. This study was set to answer the main research question: how is VET hospitality programme implemented to contribute to skills development among the trainees in Arusha region? The study employed convergent design whereby qualitative and quantitative data sets were collected concurrently. The target population involved trainers for Food and Beverages Sales and Services, Front Office Operations, trainees, heads of department, hotel managers, supervisors and graduates. Random sampling of training institutions and purposive sampling of hotels were used to determine the study sample. Data were collected through questionnaire for trainees, graduates and supervisors, classroom observation schedule, interview guide with the hotel managers and heads of department, scheduled interview with the trainers and content analysis of programme document. The findings for this study indicated that VET programme for Food and Beverages Service and Sales and Front Office Operations are not sufficiently implemented to facilitate skills acquisition among the trainees. The study recommended that VETA as the authorizing body for all VET institutions to conduct regular monitoring and evaluation in these institutions so as to ascertain whether the requirements for training provision are adhered to.
\end{abstract}

Keywords: Competence Based Education and Training (CBET), Food and Beverages Sales and Services, Front Office Operations, programme implementation

\section{Introduction}

Vocational Education and Training Authority (VETA) was established under the 1994 VET act No. 1 with the overal responsibility for ensuring the provision of required skills for effective socio-economic development in the formal and informal sectors. It trains Ordinary level graduates in vocational skills under the Vocational Education and Training (VET) covering the initial three levels (Level I -III) of the 8 levels in the TVET qualification framework. The entry requirements for Level $\mathrm{I}$ is a completion of Ordinary level education with credits in English and Mathematics. A competency certificate - National Vocational Award (NVA) is awarded after successful completion of NVA Level I or Level II which are voluntary exit points or Level III, a compulsory exit where one is regarded to have completed vocational education and training (VETA, 2013). Vocational tourism training is aimed at producing qualified people who can competently work in the lower level (operational) jobs such as receptionists, waitresses/waiters, bartenders, chefs/cooks, housekeepers and gardeners (Anderson, 2015). This study examined the programme for vocational education responsible for developing operational employees as it has been previously reported to have serious gaps in generic skills among others (Anderson, 2015).

The quality of training provided is best judged by the potential impact of equipping the graduates with the skills required by the market. Competence Based Education and Training (CBET) has been successful in producing competent graduates. Many countries in the world such as Netherlands, Ghana, Ethiopia, South Africa, Nigeria and Malawi have adopted the approach due to its anticipated benefits (Wesselink, 2010; Rutayuga, 2012; Dadi, 2014; Likisa, 2018; Dasmani, 2011; Okoye and Isaac, 2015). 
In Tanzania, Competence based education and training (CBET) in technical education and training (TET) was introduced in early 2000 to produce 'hands on graduates' with skills relevant to the labour market. The introduction of CBET was intended to facilitate a paradigm shift from the traditional Knowledge Based Education and Training (KBET) to Competence Based Education and Training (CBET) (Rutayuga, 2012). The shift from KBET to CBET is in line with the vision 2025 which envision Tanzania to be a nation of high level of education at all levels sufficiently equipped with requisite knowledge to solve societal problems, meeting the challenges of development and attain competitiveness at regional and global levels (URT, 1999). For the realization of vision 2025 and education and training programmes, competence basedVET programme for hospitality was developed in 2013 ideally reflecting the country's development plans for competent and competitive human capital. This necessitates some changes in the content design, instructional strategies and assessment approaches (Kafyulilo, Rugambuka\& Mosses, 2012). The curriculum for CBE is structured around competences that include an integrated set of knowledge, skills, and attitudes that derive their meaning from occupational contexts or task in which it is used (VETA, 2013). Mosha (2012) further asserts that a curriculum that is competency based contains specific outcomes of statements that show the competencies to be attained, behaviours or tasks to be demonstrated, conditions for their performance and acceptable standards that are shared with the students.

According to VETA (2013) CBET is based on constructivism approach and that the learner must be actively involved in the acquisition of knowledge, skills, values and attitudes. Similarly, competences selected are integrated in learning-teaching methods and assessment activities to further their acquisition and development. By doing this, the trainer's role is to guide student learning through various learner centered teaching and learning approaches. This raises a question on the dominant constructivist approaches used and how effectively they are in equipping the trainees with hospitality knowledge, skills, values and attitudes. Likewise, the integration of teaching activities and assessment methods allow for competences to be developed and assessed simultaneously (Gonczi, 1994 as cited in Wesselink, 2010). In the context of this study, are the teaching and assessment methods integrated to develop hospitality skills?

According to VETA (2013), the central point in CBET is the learner acquisition and application of learned knowledge, skills, values and attitudes in real life situations (workplace). Learners are actively engaged in the learning process and their progress is based on acquisition, demonstration and accomplishment of competence. The role of a trainer is cognitive coach, facilitator and guider. To this end, are the trainers competent enough to implement these programmes as intended? Are there opportunities for on job training to update their teaching skills? Similarly, how are the students actively engaged in the learning process? It is therefore necessary to study programme implementation in order to examine how hospitality skills are developed.

Tourism and hospitality as a labour intensive industry require possession and continuous accumulation of relevant tourism and hospitality skills and knowledge (UNECA, 2011; Anderson, 2015). Sisson and Adams (2013) assert that the growth of hospitality sector has resulted in the demand of competent employees. A study by Baum (1990) on hotels managers' expectations on graduates' entrants to the industry has identified the following key competencies as important: Management of guest problems with understanding and sensitivity, effective communication in both written and oral form, achievement of positive working relationships with employees, professional appearance and poise, development of positive customer relations and motivations of employees to achieve desired performance. Echoing Baum (1990), Sisson and Adams (2013) and Mohamad, et al (2020) argue that fresh graduates require both soft and technical skills to effectively function in the industry. These key skills are to be developed during training and on job training. Wang and Tsai (2014) assert that for hospitality graduates to successfully fulfill their roles in the job market, job competencies which serve as indicators for student employability must be identified during curricular design in order to bridge the gap between training and industry requirements.

As the industry continues growing, the need for graduates with employable skills increases. Studies on hospitality education and training have identified serious skill gaps on industry experience (Min, Swanger\&Gursoy, 2016; Gursoy, Imran \&Swanger, 2012), professional management skills (Wang \&Tsai, 2014), communication skills, team work, time management and critical thinking (Alhelalat, 2015; Spowart, 2015), lack of practical skills (Sarkodie\&Adom, 2015; Mayaka\&Akama, 2007). Similarly, it has been revealed that tourism and hospitality industry in Tanzania is challenged by lack of appropriate skilled labour (URT, 1999; 2002; Luvanda\&Shitundu, 2003). Anderson study (2015) on human resources needs and skills gaps in the tourism and hospitality sector identifies deficiency in soft skills such as communication (multilingual and interpersonal), customer care, marketing and sales skills, innovation and creativity skills, leadership and management skills and basic knowledge in Information and Communication Technology (ICT). These studies have criticized training institutions for not adequately preparing the graduates for the industry. Although these studies are mainly based on the views of the employers, there is a need to examine how these skills are developed in the classroom. Despite the fact that hospitality involved four areas of specialization namely; Food Production (FP), Housekeeping (HK), Food and Beverages Sales and Services (FBSS) and Front Office Operations (FO0), this study focused on FBSS and FOO. The selected aspects were based on previous studies that among operational employees, FBSS and F00 employees revealed more serious skills gaps (Anderson, 2015, Mbise, 2015). The researcher embarked on examining the how they were implemented to develop hospitality skills. Also, English and communication skills course as a supporting subject and foundation for developing generic skills was examined.

\section{Research Question}

This paper was guided by one research question and one hypothesis as follow:

How is hospitality programme implemented to facilitate skills acquisition among college trainees in Arusha region? 
- Ho: There is a significant mean score differences in the implementation of hospitality programme between FBSS and FOO trainees' department.

\section{Literature Review}

\subsection{Theoretical Review}

This paper is based on Tylerian objective model (1949) and Bertalanffy (1968) to assess programmes implementation in developing skills among the graduates. Objective theory aligned with the study purpose of assessing how the two programmes have developed skills among the trainees and graduates. In evaluating graduates' skills, it was important to examine how programme objectives were translated into programme inputs, developed and employed instructional procedures (process) and product. The use of objective and systems theory provided an intersection to examine how the programmes were implemented to develop knowledge, skills, attitudes and values in the graduates.

\subsection{Implementation of Hospitality Programme to Facilitate Skills Acquisition}

The implementation of Competence Based Education and Training in vocational training institutions was expected to equip the graduates with practical skills that would allow them to be successful in the workplace. With these anticipated benefits of CBET, this paper examined how hospitality programme was implemented to develop the required skills in the industry.

Kleeman (2011) explored employability skills expected of new graduates in the hospitality industry in the USA. The purpose was to gain insights into the employability skills of the new graduates and to determine if the graduates were prepared to meet the expectations of the industry. Through questionnaire as the main study instrument, it was revealed that new graduates were well prepared to meet employers' expectations. While Kleeman's study was conducted in the developed country where resources are available for teaching, the study was limited to one stakeholder (managers) and one hotel chain from which the results could be biased. The current study expanded the scope to incorporate the views of trainers, trainees, hotel managers, supervisors on how hospitality programme is implemented to facilitate skills acquisition and development. Furthermore, the researcher observed how hospitality skills are actually developed in a typical classroom situation. The purpose was to examine how trainees were engaged in learning through various strategies.

A study Sadik (2017) investigated the influence of Ghanaian hospitality industry, education and employability. The aim was to examine the effectiveness of hospitality education in meeting the industry skills requirements. The study triangulated the insights of lived experiences of students, lecturers and employers using questionnaire. The study main findings revealed acute lack of understanding of concepts of employability and the need for curriculum innovation. Moreover, it was also found that the disenabling environment for hospitality education fail to equip students with industry based employability skills. The study is commended for revealing gaps between hospitality industry and training institutions. Nevertheless, there are no evidences from this study on how employability skills are developed in a typical classroom situation. The way trainees are encouraged to engage in varieties of classroom based activities should as well be studied to examine how the skills are developed. Sadik's study is commended for recommending innovation in curriculum among others; however, for successful curriculum innovation to occur there should be a holistic curriculum evaluation in the design, implementation, evaluation. The current study is intended to examine how hospitality programme is implemented to enhance skills development among the trainees in Arusha.

Khutsafalo and Makambe (2020) conducted a survey study in Botswana to explore the nexus between pedagogical strategies and motivation of hospitality management learners. The aim was to investigate the role of pedagogical strategies in facilitating learner motivation in the selected higher education institutions. The findings revealed that lack of enough opportunities for learners to do presentations and weakness in curriculum to produce graduates who would meet the industry needs had negative effects on learner motivation. The study is commended for revealing the importance of incorporating technology in teaching and learners' positive motivation. The current study examined how hospitality programme is implemented to enhance skills development.

Likewise, Pratt \&Hahn (2016) study that examines hospitality students learning through simulation in Australia contends that simulation as an example of constructive learning encourages student engagement and the development of problem solving skills (PBL). Yilmaz (2011) study on the cognitive perspectives on learning in Turkey asserts that the use of cognitive apprenticeship, inquiry learning, discovery learning and problem based learning (PBL) as effective teaching methods that support constructivist learning. Similarly, Cheng (2013) study on effectiveness of project based course learning within hospitality programme in Taiwan suggests that students who participate in PBL activities exhibit active involvement and encouraged to solve real world problems using knowledge previously gained in the classroom. Therefore, this study examined how hospitality programme was implemented to enhance skills development among the trainees in Arusha region.

\section{Research Methodology}

The study employed convergent design to comparewhetherqualitative and quantitative dataconfirm or disconfirm each other.The purpose was to obtain different but complementary data on the same research to best understand the research problem (Creswell and Creswell, 2018).

The study targeted allprivate Vocational Education and Training (VET) hospitality training institutions and members of Hotels Association of Tanzania (HAT) inArusha region. The sample for the study was six (6) training institution which were randomly selected. The 18 hotels were selected by purposive sampling technique. A total sample of 
294 respondents was included in the study. Key informants in the training institutions and hotels were purposively selected. These included 18 trainers, 6 heads of department, 108 trainees, 18 hotel managers, 36 supervisors and 108 workers.

Data for this study was collected through questionnaire for trainees, workers and supervisors, interview guide for heads of department and hotel managers, interview schedule for trainers. Classroom observation schedule and document analysis guide were used to triangulate information from various respondents.

Validity of the instruments was determined by research experts and reliability of the questionnaire was tested by Cronbach Alpha technique. Cronbach Alpha coefficient of $0.875,0.866$ and 0.786 were obtained for trainees, workers and supervisor questionnaires respectively.The questionnaires were reliable because according to Kerlinger (2000), a value of Cronbach 0.7 is considered to be a cut off for acceptable and unacceptable reliability. Trustworthiness of qualitative data was ensured by triangulation and member checking.

Qualitative data were analyzed by transcription of data from interviews and document analysis. Coding of data was done accordingly, themes and categories were developed and interpretation was done according to the context. Descriptive and inferential statistics were used for quantitative data analysis. Summary of data were presented in frequencies, percentages and means. Independent sample T-test was used to test hypothesis at 0.05 significance level.

\section{Results and Discussion}

The aim of this paper was to examine how hospitality programme is implemented to facilitate skills acquisition among the graduates. Specifically, the researcher was interested in determining how learning content, teaching methods, resources used and assessment activities were implemented to develop hospitality skills.This section presents implementation of hospitality programme in facilitating skills acquisition.Table 1 delineates trainees and graduates responses on how Front Office Operations (FOO) and Food and Beverage Sales and Services (FBSS) are implemented to develop hospitality skills, knowledge, values and attitudes. Trainees for F00 ( $=41)$, FBSS ( $=48)$, graduates FBSS (n=45) and FOO $(\mathrm{n}=45)$.

\begin{tabular}{|c|c|c|c|c|c|c|c|c|c|c|c|c|c|c|}
\hline \multirow{2}{*}{$\begin{array}{c}\text { Functional } \\
\text { Areas } \\
\end{array}$} & \multirow[b]{2}{*}{ Respondent } & \multicolumn{2}{|c|}{$\begin{array}{c}\text { Strongly } \\
\text { Disagree }\end{array}$} & \multicolumn{2}{|c|}{ Disagree } & \multicolumn{3}{|c|}{ Not Sure } & \multicolumn{2}{|c|}{ Agree } & \multicolumn{2}{|c|}{$\begin{array}{c}\text { Strongly } \\
\text { Agree }\end{array}$} & \multirow[t]{2}{*}{ Mean } & \\
\hline & & $\mathbf{F}$ & $\%$ & \multicolumn{2}{|c|}{$\mathbf{F}$} & $\%$ & & $\mathbf{F}$ & $\%$ & \begin{tabular}{l|l|} 
F & $\%$ \\
\end{tabular} & $\mathbf{F}$ & $\%$ & & \\
\hline \multicolumn{14}{|c|}{ Learning content } & \\
\hline \multirow{13}{*}{$\begin{array}{c}\text { Hospitality } \\
\text { knowledge, skills } \\
\text { and values are } \\
\text { integrated into } \\
\text { learning activities }\end{array}$} & Trainees & & & & & & & & & & & & & \\
\hline & FOO & 2 & 4.9 & 1 & \multicolumn{2}{|c|}{2.4} & 0 & 0 & 15 & 36.6 & 23 & 56.1 & 4.37 & \\
\hline & FBSS & 4 & 8.3 & 4 & \multicolumn{2}{|c|}{8.3} & 4 & 8.3 & 26 & 54.2 & 10 & 20.8 & 3.71 & \\
\hline & Graduates & & & & & & & & & & & & & \\
\hline & FOO & 0 & 0 & 0 & \multicolumn{2}{|c|}{0} & 0 & 0 & 45 & 100 & 0 & 0 & 4 & \\
\hline & FBSS & 0 & 0 & 0 & \multicolumn{2}{|c|}{0} & 0 & 0 & 45 & 100 & 0 & 0 & 4 & \\
\hline & Trainees & & & & \multirow{2}{*}{\multicolumn{2}{|c|}{29.3}} & & & & & & & & \\
\hline & FOO & 14 & 34.1 & 12 & & & 4 & 9.8 & 8 & 19.5 & 3 & 7.3 & 2.37 & \\
\hline & FBSS & 7 & 14.6 & 15 & \multicolumn{2}{|c|}{31.2} & 8 & 16.7 & 12 & 25 & 6 & 12.5 & 2.9 & \\
\hline & Graduates & & & & & & & & & & & & & \\
\hline & FOO & & & & & & & & & & & & & \\
\hline & FBSS & 6 & 13.3 & 2725 & 60 & & 0 & 0 & 0 & 0 & 12 & 26.7 & 2.67 & \\
\hline & & 6 & 13.3 & & 55. & & 0 & 0 & 0 & 0 & 14 & 31.1 & 2.8 & \\
\hline \multicolumn{15}{|c|}{ Teaching and training methods } \\
\hline \multirow{6}{*}{$\begin{array}{l}\text { Trainers are not } \\
\text { using varieties of } \\
\text { strategies that } \\
\text { engage us in } \\
\text { learning }\end{array}$} & Trainees & 1 & 2.4 & 1 & 2.4 & 8 & & 19.5 & 21 & 51.2 & 10 & & 4.4 & 1 \\
\hline & F00 & 6 & 12.5 & 4 & 8.3 & 4 & & 8.3 & 26 & 54.2 & 8 & & 6.7 & 1.5 \\
\hline & FBSS & & & & & & & & & & & & & \\
\hline & Graduates & & & & & & & & & & & & & \\
\hline & FOO & 12 & 26.7 & 0 & 0 & 0 & & 0 & 25 & 55.6 & 8 & & 7.8 & 1.6 \\
\hline & FBSS & 13 & 28.9 & 0 & 0 & 0 & & 0 & 26 & 57.8 & 6 & & 3.3 & 1.73 \\
\hline We are not given & Trainees & & & & & & & & & & & & & \\
\hline opportunities to & FOO & 6 & 14.6 & 4 & 9.8 & 6 & & 14.6 & 14 & 34.1 & 11 & & 6.8 & 2.5 \\
\hline learning through & FBSS & 7 & 14.6 & 13 & 27.1 & 4 & & 8.3 & 13 & 27.1 & 11 & & 2.9 & 2.2 \\
\hline various & Graduates & & & & & & & & & & & & & \\
\hline classroom & FOO & 0 & 0 & 0 & 0 & 6 & & 13.3 & 15 & 33.3 & 24 & & 3.3 & 1.6 \\
\hline workshops/demo & FBSS & 0 & 0 & 1 & 2.2 & 5 & & 11.1 & 12 & 26.7 & 27 & & 60 & 1.51 \\
\hline kitchen & & & & & & & & & & & & & & \\
\hline & Trainees & & & & & & & & & & & & & \\
\hline $\begin{array}{l}\text { learning } \\
\text { materials include }\end{array}$ & FOO & 1 & 2.4 & 4 & 9.8 & 5 & & 12.2 & 15 & 36.6 & 16 & & 39 & 4 \\
\hline hands on & FBSS & 2 & 4.2 & 9 & 18.8 & 6 & & 12.5 & 20 & 41.7 & 11 & & 2.9 & 3.6 \\
\hline
\end{tabular}




\begin{tabular}{|c|c|c|c|c|c|c|c|c|c|c|c|c|}
\hline \multicolumn{13}{|l|}{ experiences } \\
\hline & Graduates & & & & & & & & & & & \\
\hline & FOO & 0 & 0 & 0 & 0 & 6 & 13.3 & 27 & 60 & 12 & 26.7 & 4.13 \\
\hline & FBSS & 0 & 0 & 0 & 0 & 7 & 15.6 & 25 & 55.6 & 13 & 28.9 & 4.13 \\
\hline \multicolumn{13}{|c|}{ Assessment } \\
\hline \multirow{6}{*}{$\begin{array}{c}\text { Assessment } \\
\text { activities given } \\
\text { do not guide our } \\
\text { learning }\end{array}$} & Trainees & & & & & & & & & & & \\
\hline & F00 & 9 & 22 & 8 & 19.5 & 1 & 2.4 & 6 & 14.6 & 17 & 41.5 & 2.3 \\
\hline & FBSS & 11 & 22.9 & 4 & 8.3 & 8 & 16.7 & 7 & 14.6 & 15 & 37.5 & 2.5 \\
\hline & Graduates & & & & & & & & & & & \\
\hline & FOO & 8 & 17.8 & 12 & 26.7 & 0 & 0 & 6 & 13.3 & 19 & 42.2 & 2.1 \\
\hline & FBSS & 6 & 13.3 & 14 & 31.1 & 0 & 0 & 6 & 13.3 & 19 & 42.2 & 1.9 \\
\hline \multirow{7}{*}{$\begin{array}{c}\text { Assessment } \\
\text { activities } \\
\text { required trainees } \\
\text { to demonstrate } \\
\text { competence } \\
\text { through } \\
\text { performance of } \\
\text { tasks }\end{array}$} & Trainees & & & & & & & & & & & \\
\hline & FOO & 8 & 19.5 & 7 & 17.1 & 11 & 26.8 & 8 & 19.5 & 7 & 17.1 & 2.2 \\
\hline & FBSS & 9 & 18.8 & 6 & 12.5 & 7 & 14.6 & 21 & 43.8 & 5 & 10.4 & 2.4 \\
\hline & Graduates & & & & & & & & & & & \\
\hline & FOO & 0 & 0 & 6 & 13.3 & 0 & 0 & 6 & 33 & 73 & 13.3 & 2.3 \\
\hline & FBSS & 1 & 2.2 & 7 & 15.6 & 0 & 0 & 7 & 30 & 66.6 & 15.5 & 2.5 \\
\hline & & & & & & & & & & & & \\
\hline \multirow{6}{*}{$\begin{array}{l}\text { Trainers always } \\
\text { discuss } \\
\text { assessment } \\
\text { results with the } \\
\text { trainees as a } \\
\text { feedback for } \\
\text { learning }\end{array}$} & Trainees & & & & & & & & & & & \\
\hline & FOO & 5 & 12.2 & 1 & 2.4 & 4 & 9.8 & 12 & 29.3 & 19 & 46.3 & 3.95 \\
\hline & FBSS & 0 & 0 & 4 & 8.3 & 6 & 12.5 & 24 & 50 & 14 & 29.2 & 4 \\
\hline & Graduates & & & & & & & & & & & \\
\hline & FOO & 6 & 13.3 & 7 & 15.6 & 0 & 0 & 18 & 40 & 14 & 31.1 & 3.6 \\
\hline & FBSS & 7 & 15.6 & 6 & 13.3 & 0 & 0 & 20 & 44.4 & 12 & 26.7 & 3.53 \\
\hline
\end{tabular}

Table 1:Trainees and Graduates Responses on Programmes Implementation Source: Field Data (2021)

\subsection{Learning Content}

The objective of hospitality programme is to develop professional skills, knowledge, values and attitudes to people who aspire to work in the hospitality industry (VETA, 2013). The learning content was prepared to examine how they are integrated into the requirements of hospitality industry. It was found out that all learning activities were rated above mean score for both trainees and graduates. Therefore, learning activities as rated by trainees and graduates were satisfactory for hospitality training. If the trainees and graduates are satisfied with learning activities offered in their training, they are likely to be motivated to learn towards achieving designated learning outcomes.

These findings were supported by interview with the heads of department that the designed learning activities and the inclusion of supporting subjects provide a balance in teaching and learning of hospitality knowledge, skills, values and attitudes. Similarly, classroom observation data revealed all learning content for FO0, FBSS and English and communication skills were integrated into hospitality knowledge, skills, values and attitudes. Thus the extent to which learning activities reflect future job occupation is important in the programme implementation and the realization of competence to be acquired. Tyler (1949) urges that programme objectives should be the basis through which contents are organized to enable the learner to acquire and develop desired learning outcomes. Both quantitative and qualitative data gathered have confirmed on the alignment of programme objectives and learning activities.

\subsection{Teaching and Training Methods}

Teaching and training methods provide an avenue through which trainers and trainees interact. In CBET, teaching and training methods are learner centered- actively engaging trainees to construct meaning through discussions, reflections and sharing ideas with others (Nzima, 2016). As indicated in Table 1 criteria such as the use of various strategies and opportunities to demonstrate learning were rated below the average mean scoreby both trainees and graduates. Findings from structured interview with the trainers on teaching and training methods revealed that common methods used were lectures, questions and answers, group discussion, demonstrations. Lecture method was dominant as it was considered by the trainers to cover large contents before trainees were given opportunities to demonstrate knowledge gained. This response matched the interview with the heads of department on the dominant method of teaching. One of the heads of department said,

'....yah lecture covers lots of content, if you use student centered methods, you will not finish the course' (7/5/21). Two important concepts can be derived from these extracts; number one is the programme objectives and two is the perception on student centered methods. The programme specifies that learning is through application where trainees are involved in practical oriented activities. Further, in CBET the focus in on what competence in terms of skills, knowledge, values and attitudes the learner has acquired and not how much contents have been covered. The tendency to resort to lecture method to cover the content does not facilitate the acquisition of intended practical skills.

Findings from classroom observation revealed lecture method dominated teaching and training process. Most of the instructional time was spent through trainer talk -explanation of concepts, asking questions with no opportunities for trainees' interaction. Topics were introduced and explained to the trainees who were busy jotting down trainer's explanations. In college A, for example during FBSS session explanations on types of beverages were all written on the 
board for trainees to copy, followed by trainer talk on the types of beverages. Oral questions asked required trainees reproduced trainer's notes. There were neither teaching materials used nor opportunities for trainers to interact. This practice was common in the selected colleges and does not foster acquisition and development of required hospitality competence. Studies on hospitality training have urged on the effective use of simulation learning. Pratt and Hahn (2016) have urged that simulation learning develop problem solving skills, teamwork skills which ultimately improve communication skills. Job related competence cannot be learnt through lecturing as found out in this study.

Although tasks such as debating, oral questions and quizzes were given before and after the session, only handful of trainees participated. Others were mostly observers of how other trainees participated with no efforts to engage them. These findings are consistent with Khutsafalo and Makambe (2020) study in Botswana which revealed that lack of opportunities for learners to do presentations impede graduates from acquisition of hospitality skills. On the other hand, Boahin (2018) asserts that competence based training require learners to be engaged in a range of activities to ensure acquisition of competences to perform professional tasks. Since the kind of performance tasks that trainees were engaged in were not cognitively challenging, it is likely that they will not acquire intended practical skills.

The analysis of trainers' demographic information revealed that only 43.7 percent of trainers have attended inservice professional development on CBET. While CBET is a new paradigm, effective preparation of trainees is important so as to realize the intended outcomes. Fullan (2010) urges that education change depends on what teachers do and think. If trainers who are the programme implementers have not grasped what is expected from them in the new programme, they are likely to resist the changes. Likewise, for heads of departments who are expected to provide instructional leadership in programme implementation, only 16.6 percent have attended in-service professional development on CBET. Thus, with the lack of training on CBET, heads of department may not visualize the importance of CBET on graduates' skills acquisition, and hence, not support its effective implementation. Hospitality education as a dynamic system requires integration of activities to realize the designated outcomes (Bertalanffy, 1968). Trainers as implementers and heads of department need to have a clear conceptualization of CBET and embrace the changes in classroom roles so that the objectives of CBET are realized.

Even though the observed sessions had similar structure in terms of teaching and training methods, there were occasions some trainers used a different pattern. In college D during FBSS session, trainer had prepared guided questions for trainees to demonstrate competence on types of beverages. The questions required trainees to identify types of beverages based on the contents (ingredients) suitable in various occasions. Trainees worked in groups of four (4) and with the aid of sample bottles of beverages, they were able to identify beverage types suitable in various occasions. In another session at college $\mathrm{C}$ during FOO session trainees were guided to role play how to fill and process reservation form. Trainees practiced receptionist-guest relationship in filling out the form while other class members were watching inquisitively and trainer jotting down how the process was done. At the end of the session, feedback for learning was given to trainees who seemed to be very satisfied with the efforts done. The illustration revealed that where trainees are guided to demonstrate competence through practical activities, they develop interest and motivated to learn. These findings concur with Kouwenhoven (2003) who asserts that the acquisition and development of competence occur through designed learning tasks in a meaningful context. The context through which learning occurs is important for acquisition and development of competence. Role play and direct interaction provide opportunities for students to acquire and perform professional tasks (Boahin, 2018). Through guided activities and use of 'rich' and stimulating materials trainees acquired designated competence. The importance of assistance relates to Vygotsky 's (1978) concept of zone of proximal development that describes the distance between what a learner can do by himself and the next level where he needs assistance for knowledgeable others. In his view learning takes place through social interaction with peers and knowledgeable others. The use of student centered methods provide opportunities for individual student to acquire knowledge and construct meaning through discussions, reflections and sharing ideas with other students (Nzima, 2016; Tilya\&Mafumiko, 2010; Konwenhoven, 2003).

\subsection{Resources}

Teaching and training resources are integral part in facilitating the acquisition and development of hospitality competence. Effective use of teaching and training materials stimulates trainees' interest to participate in learning. The inclusion of hands on teaching and learning materials was rated as very good by the trainees and graduates. This indicates that they were efforts to use various resources to facilitate the teaching-learning process. Nevertheless, during classroom observation the use of materials to stimulate trainees' interest in learning was scored below the mean. This implies that trainees are not exposed to stimulating materials; thus learning concepts in abstracts. This practice negatively impact on acquisition of practical skills. Findings from trainers' interview on the availability of training resources revealed that most colleges do not have enough facilities and teaching resources. Trainers depend much on familiarization visits to demonstrate practical activities. In one of the colleges, the head of department said;

'...well since our programmes demand practical oriented activities, we have a hotel nearby here where our trainees go for practical' $(27 / 5 / 2021)$.

Important elements to be noted from this illustration are that colleges are required to have their own facilities and resources for training before being registered. Another thing is how often trainees go for familiarization in the hotels. Should the trainees wait for familiarization visits to be acquainted with practical skills or that should have been done during training before they go for familiarization visits. This is contrary to Kolb (1984) that learning is a process through which knowledge is created through transformation of experiences.

Similarly, managers further questioned on the availability of training materials in colleges. One of the managers

said, 
'I'm wondering if these colleges have the required resources. You find during their familiarization visits, trainees are told these are the restaurant cutleries that I (trainer) was telling you about and you wonder whether that was the first time trainees see the cutleries' $(8 / 6 / 21)$.

Managers' observations cannot be overemphasized, interviews andclassroom data revealed similar findings were prepared teaching materials were rated below average in all courses. These findings concur with Dasmani (2011) in Ghana, Rotich, et al (2012) in Kenya that shortage of training materials negatively impact trainees' skills acquisition. It can therefore be said that a serious shortage of teaching materials has a detrimental effect on the acquisition of the required hospitality competence.In absence of no or few opportunities for trainees to demonstrate learning, the indication is that trainees are not actively engaged in hands on activities and hence they are likely not to acquire practical skills most required on their future occupations. Therefore, lack of supportive teaching and training resources hinder effective implementation of CBET hospitality programme and acquisition of the required hospitality competences.

\subsection{Assessment}

This part was intended to examine whether assessment activities guided acquisition of competence in terms of knowledge, skills, values and attitudes. As indicated in the table 1, criteria such as assessment to guide learning, assessment through performance of tasks were scored below the average for trainees and graduates in FOO and FBSS. Nevertheless, it was reported that feedback for learning was rated above average by all trainees and graduates in FO0 and FBSS. Assessment activities were intended to improve teaching and learning process. Guliker (2006) asserts that when learning activities are aligned with assessment, students are stimulated to study intensively and they develop competences. Assessment activities provided did not assist both trainees and graduates to acquire and develop the required competence.

Findings from trainers and heads of department interview showed that the dominant assessment practices are tests, quizzes, examinations and in few occasions practical. From these practices, tests and quizzes were dominant. Tests are mainly based on theoretical knowledge, as opposed to practical knowledge required by the programme. There were few evidences on how assessment activities integrate hospitality knowledge, skills, values and attitudes. Aligning assessment and learning activities enable students to learn what they think they will be assessed (Biggs, 2002) and construct meaning through relevant activities (Kouwenhoven, 2003). Interview data revealed that trainers solely use oral questioning and demonstration to assess trainees. In one of class sessions observed in English and communication skills, trainees were practicing conversation with guests. Although they were guided on the topics for conversations, assessment on how they have managed to communicate with one another was not done. The absence of feedback on the tasks performed does not encourage the efforts done on the tasks. Boahin (2018) urges that feedback on assessment tasks build students' self-esteem to self-regulate their learning towards the achievement of learning goals. Data from classroom observation revealed that even when the trainees were required to demonstrate a given task, rubrics were not used to record how a trainee has exhibited various competences (how the task was performed). The purpose of assessment is to collect sufficient evidence that the trainee can perform to specified standards in a specific role (VETA, 2013). Criteria such as rubrics, portfolio, observations, written examinations, peer and self-assessment can be used to assess a number of elements of competence and their performance criteria (Prinsloo, 2001; Kouwenhoven, 2003; Boahin, 2018). Therefore, assessment activities were not meant to improve trainees' mastery of hospitality skills.

As indicated in Table 1 items such as assessment activities reflect future professional practice and assessment activities to develop students' skills in hospitality were weakly rated for FOO, FBSS and English and communication skills. The implication is trainees do not make a sense of how assessment activities guide in the acquisition of hospitality competence. On the other hand, students feedback on their assignments were rated good for FOO and FBSS, while for English and communication skills was weakly rated. Assessment for learning is an integral part in the implementation of CBET. According to VETA (2013), each unit has to be assessed and the trainee has to meet the required standard before proceeding to the next unit. This indicates that assessment is formative in nature and trainer is expected to design multiple assessment activities for informing and stimulating learning (Misbah, 2019). Based on the observation data, assessment activities were neither developing trainees' hospitality skills as they were mostly theoretical nor reflecting their future professional and improving learning and teaching process.

Industry participation in the training process is important for trainees to get up to date knowledge, skills and practical overview of subject matter from industry professional (Gursoy, et al 2012). Although trainers and heads of department have all agreed on the importance of engaging the industry in the training process, none has ever asked someone from the industry to participate in the training. A follow up interview with hotel manager revealed the same that none of the interviewed hotel manager has ever been asked to participate in the training. It was further asked whether, if invited what concepts they would have emphasized. Their responses insisted on practicing generic skills such as effective communication, and to have passion towards the industry. One of the managers said,

'people think that anybody can work in the hospitality industry, your passion, attitude and effective communication will make you survive in the industry' (14/6/21).

This was confirmed by Cox (2015) and Yao-Fen and Chen-Tsang (2014) that competence in generic skills is the basis for successful hospitality industry. Findings from this study revealed that English and Communication skills is not give the attention it deserves. Despite the fact that the course is vital for developing trainees communicative competence; the intended learning outcomes have not being identified thus creating hurdles to its effective implementation.

A hypothesis was also tested to determine whether or not there was a significant difference between in the implementation of programme between FBSS and FOO trainees' department.Independent sample T-test was run and found that $\mathrm{T}(-0.018=0.00210$ and $\mathrm{p}$-value $=0.986)$. The findings indicate that $\mathrm{p}$ - value $(0.986)$ is greater than the 
significance level (0.05). Hence, the null hypothesis is not rejected. Therefore, there is no significant difference in the mean score of implementation of FBSS and FOO programmes.

\section{Conclusion}

There is little evidence to suggest that private VET training institutions in Arusha sufficiently implement the programme to facilitate skills acquisition and development among the trainees Both quantitative and qualitative data have indicated that trainees were not actively engaged in the lesson to acquire the required hospitality competence. In the same line, inadequate training resources hindered the acquisition of practical skills component important in their future workplace.

\section{Recommendations}

The researcher would like to recommend the following:

- $\quad$ VETA as the authorizing body for all VET institutions should conduct regular monitoring and evaluation to these institutions so as to ascertain whether the requirements for training provisions are adhered.

- VETA should emphasize on the availability of the required teaching and training materials before an institution is authorized to offer hospitality training.

- Training institutions should provide regular seminar/workshops, as part of in-service professional development on the Competence Based Education and Training (CBET) as opposed to depend on trainer's personal initiatives.

\section{References}

i. Alhelalat, J.A. (2015). Hospitality and non hospitality graduate skills between education and industry. Journal of Business Studies Quartely, 6(4), 46 - 55.

ii. Anderson, W. (2015). Draft report on Human resource needs and skills gap in the tourism and hospitality sector, MoESTVT.

iii. Ansah, S. K. \& Ernest, K. (2013). Technical and Vocational education and training in Ghana: A tool for skill acquisition and industrial development. Journal of Education and Practice, Vol.4 (16).

iv. Asirifi, G. H., Doku, V., Morrison, S. \& Sackey, A.S. (2013). The gap between the hospitality education and hospitality industry. Journal of Education and Practice. Vol.4,No.24.

v. Association of Tanzania Employers (ATE), (2011). Skills development assessment, JE Austin Associates, Arlington, U.S.A.

vi. Bertalanffy, L. (1968). General system theory: Foundation, development, application, University of Alberta, Canada.

vii. Biemans, H. J. A., Wesselink, R., Gulikers, J. T., Schaafsma, S., Verstegen, J., \& Mulder, M. (2009). Towards competence-based VET: dealing with the pitfalls. Journal of Vocational Education and Training, 61 (3), $267-286$.

viii. Biemans, H. J., Nieuwenhuis, L., Poell, R., Mulder, M., \& Wesselink, R. (2004). Competence based VET in the Netherlands: backgrounds and pitfalls. Journal of Vocational Education and Training, 56(4), 523-538.

ix. Boahin, P. (2018). Competence based curriculum: A framework for bridging teaching, assessment and the world of work. International Journal of Vocational and Technical Research, Vol.4(2) 1-15.

x. Cheng, S. (2013). An empirical investigation of the effectiveness of project-based course learning within hospitality programs: the mediating role of cognitive engagement. Journal of Hospitality, Leisure, Sports \& Tourism Education, 13, 213-225. Doi: 10.1016/j.jhlste.2013.10.002.

xi. Cheung, C., Law, R. \& He, K. (2010). Essential hotel managerial competencies for graduate students. Journal of Hospitality and Tourism Education, 22(4), 25-32.

xii. Creswell, J.W. \& Creswell, D.J. (2018). Research design: Qualitative, quantitative and mixed methods approaches ( $5^{\text {th }}$ ed.), Los Angeles, USA, Sage Publications.

xiii. Creswell, J.W. (2014). Research design: Qualitative, quantitative and mixed methods approaches (4th ed.), California, USA, Sage Publications.

xiv. Dewey, J. (1938). Experience and education. New York: Macmillan Publishing Company.

xv. Freire, P. (1972). Pedagogy of the oppressed, Harmondsworth: Penguin

xvi. Gulikers, J., Biemans, H. \& Mulder, M. (2009). Developer, teacher, student and employer evaluations of competence based assessment quality, Studies in Educational Evaluation 35, 110 - 119.

xvii. Gursoy, D., Imran, R. \&Swanger (2012). Industry's expectations from hospitality schools: What has changed? Journal of Hospitality \&Tourism Education, 24:4, 32-42.

xviii. HAT. (2020). Member directory: HAT \& Affiliate Members. HAT.

xix. Hennemann, S., \& Liefner, I. (2010). Employability of German geography graduates: Journal of Geography in Higher Education, 34(2), 215-230.

xx. Kafyulilo, A.C., Rugambuka, I.B. \&Mosses, I. (2012). Implementation of Competence Based Teaching in Morogoro Teachers' Trainining College, Tanzania. Makerere Journal of Higher Education, 4(2), 311-326.

xxi. Kolb, D. A. (1984). Experiential learning: Experience as the source of learning and development, Englewood Cliffs, NJ: Prentice Hall.

xxii. Kouwenhoven, W. (2003). Designing for competence in Mozambique: Towards a competence-based curriculum for the Faculty of Education of the Eduardo Mondla neUniversity. PhD Dissertations, University of Twente.

xxiii. Luvanga, N. and J. Shitundu. (2003). The role of tourism in poverty alleviation in Tanzania.Mkuki na Nyota Publishers. Dar es Salaam. Research report No. 034. 
xxiv. Mayaka, M. \& Akama, J.S. (2007). Systems approach to tourism training and education: The Kenyan case study. Tourism Management, 28, 298-306. Accessed from:www.elservier.com/locate/tourism.

xxv. Mbise, E. (2015). Challenges facing tourist hotels towards provision of good customer services: The case of tourist hotels in Arumeru district, Arusha region. Master thesis, Open University of Tanzania.

xxvi. Min, H., Swanger, N. \& Gursoy, D. (2016). A longitudinal investigation of the importance of course subjects in the hospitality curriculum: An industry perspective. Journal of Hospitality \& Tourism Education, 28(1), 10-20.

xxvii. Ministry of Natural Resources and Tourism. (1999). National Tourism Policy, United Republic of Tanzania.

xxviii. Ministry of Natural Resources and Tourism. (2002). Tourism Master Plan, United Republic of Tanzania.

xxix. Ministry of Natural Resources and Tourism. (MNRT, 2014). Tourism statistical bulletin, Tourism division.

xxx. Nzima, I. (2016). Competence-based curriculum (CBC) in Tanzania: Tutors' understanding and their instructional practices, Doctoral dissertation, Department of Pedagogy, Linnaeus University, Vaxjo, Sweden.

xxxi. Phelan, K.V., Mejia, C., \& Hertzman, J. (2013). The industry experience gap: Hospitality faculty perceptions of the importance of faculty industry experience. Journal of Hospitality and Tourism Education, 25(3), 123-130.

xxxii. Pratt, M.A. \& Hahn, S. (2016). Enhancing hospitality student learning through the use of business simulation,Journal of Hospitality, Leisure, Sports \& Tourism Education, 19, 0-18. Doi: 10.1016/j.jhlste.2016.05.001.

xxxiii. Rasul, M. \& Mansor, A.N. (2013). Employability skills indicator as perceived by manufacturing employers, Asia Social Science, 9(8): 42-46.

xxxiv. Rotich, D., Sawe, J.B.\&Akgul, K. (2012). Assessment of quality of hospitality education in Kenya, Journal of Emerging Trends in Educational Research and Policy Studies,3(5):675-679.

xxxv. Rutayuga, B.A. (2014). The emerging Tanzania concept of competence: Conditions for successful implementation and future development. A thesis submitted to the Institute of Education, University of London in Partial Fulfillment of the Requirements for the Degree of Doctor of Philosophy.

xxxvi. Sarkodie, A. \& Adom, K. (2015). Bridging the gap between hospitality education and hospitality industry in Ghana. International Journal of Research in Humanities and Social Studies, Vol.2(7), 114-120. Sryahwa Publications.

xxxvii. Sarkodie, N. A.(2018). Assessing hospitality training and practices in Ghana. African Journal of Hospitality, Tourism and Leisure, Volume 7(1).

xxxviii. Shariff, N.M. (2013). Reforming hospitality education to fulfill the industry expectations: A case of University of Utara Malaysia. Academic Research International, 4(2).

xxxix.Sisson, L.G., \& Adams, A. R. (2013). Essential hospitality management competencies: The importance of soft skills. Journal of Hospitality and Tourism Education, 25(3), 131-145.

xl.Solomon, G. H. (2016). Towards competence based technical-vocational education and training in Ethiopia. Doctoral Degree Dissertation, Wageningen: Wageningen University and Research.

xli. Stansbie, P., Nash, R. \& Chang, S. (2016). Linking internships and classroom learning: A case study examination of hospitality and tourism management students. Journal of Hospitality, Leisure, Sport \& Tourism Education, 19, 1929.

xlii. TCU. (2019). Quality Assurance: General guideline and minimum standards for provision of University Education in Tanzania (3rd ed.) Tanzania Commission for Universities. Dar es salaam.

xliii. Tourism Hospitality Professionals Association of Tanzania (THPAT). (2013).

xliv. Tsai, Y. H. (2017). Travel agency managers' perceptions of tourism industyr employability. Journal of Hospitality, Leisure, Sport and Tourism, 20, 122-133. Doi: 10.1016/j.jhlste.2017.04.001.

xlv. Tyler, R.W. (1949). Basic principles of curriculum and instruction, Chicago, University of Chicago Press.

xlvi. United Republic of Tanzania (1994): Vocational Education and Training Act, Dar es Salaam.

xlvii. United Republic of Tanzania. (2012). Tanzania Tourism Sector Survey (TTSS), International Visitors' Exist Survey report.

xlviii. United Republic of Tanzania.(2000). The Tanzania Development Vision 2025. Planning Commission, Dar es salaam, United Republic of Tanzania.

xlix. VETA, (2012). Report on the labour market survey for TVET in Tanzania, VETA.

l. VETA, (2013). Curriculum for hospitality, VETA.

li. Wesselink, R. (2010). Comprehensive competence based vocational education: The development and use of a curriculum analysis and improvement model. Wageningen University. The Netherlands.

lii. Yan, H., \& Cheung, C. (2012). What types of experiential learning activities can engage hospitality students in Chinal? Journal of Hospitality \& Tourism Education, 24(2-3), 21-27. Doi: 10.1080/10963758.2012.10696666.

liii. Yilmaz, K. (2011). The cognitive perspective on learning: Its theoretical undepinnings and implications for classroom practices. The Clearing House, 84(5). Doi:10.1080/00098655.2011.568989. 